\title{
NEODRŽIVOST TRADICIONALNOG OBRAZOVANJA U SUZBIJANJU MARGINALIZACIJE ${ }^{1}$
}

\author{
Sofija Vrcelj \\ Filozofski fakultet, Sveučilište u Rijeci, Republika Hrvatska \\ Siniša Kušić \\ Filozofski fakultet, Sveučilište u Rijeci, Republika Hrvatska \\ Anita Zovko \\ Filozofski fakultet, Sveučilište u Rijeci, Republika Hrvatska
}

\begin{abstract}
Sažetak
$\mathrm{U}$ radu se analizira marginalizacija s posebnim osvrtom na marginalizaciju u obrazovanju. lako je (obrazovna) marginalizacija sklizak konstrukt, ona postoji u svim društvima i zahvaća različite skupine ljudi. Tradicionalni pristupi obrazovanju, koji generiraju marginalizaciju, i pored određenih pokušaja pokazali su svu nemoć u njezinom suzbijanju u obrazovanju čime se nameće potreba kreiranja drugačijeg obrazovanja koje će omogućiti osnaživanje marginaliziranih. Na razini škola osnaživanje je proces u kojem sudionici razvijaju kompetencije potrebne za preuzimanje odgovornosti za vlastiti rast i rješavanje vlastitih problema dok je na međunarodnoj i nacionalnoj razini proces i akcije koje daju dopuštenje nastavnicima da prilagode kurikulume i pedagogiju kako bi se zadovoljile potrebe učenika.
\end{abstract}

Ključne riječi: obrazovanje, marginalizacija, odrasli, kurikulum

\section{UvoD}

Marginalizacija pojedinaca, grupa i zemalja stvarnost je u gotovo svakom društvu i u svakom razdoblju ljudske povijesti. Cijela društva mogu biti marginalizirana na globalnoj razini, dok klase i zajednice mogu biti marginalizirane od dominantnog društvenog poretka. Isto tako, etničke skupine, obitelji ili pojedinci mogu biti marginalizirani unutar lokaliteta (Pelc, 2017). U određenoj mjeri marginalizacija je promjenjiva pojava povezana s (društvenim) promjenama. Pojedinac ili grupa(e) mogu u određenom vremenu imati visok društveni status, ali uslijed (društvenih) promjena mogu izgubiti taj status i postati marginalizirani. Isto tako, osoba može biti pozicionirana na margine zbog životnog ciklusa, spola, izgleda, vjerskog uvjerenja, seksualne orijentacije, obrazovanja i drugih razloga koji se uzimaju relevantnim na globalnoj i lokalnoj razini. Marginalizacija je historijski, kompleksan, multikauzalan i sklizak konstrukt koji je uveo Robert E. Park 1928. godine u radu „Human Migration and the Marginal Man” (Bankovskaya, 2014; Déry, Leimgruber i Zsilincsar, 2012). Park se početkom 20. stoljeća u Americi suočio s ogromnom etničkom raznolikošću talijanskih, poljskih, irskih, ukrajinskih i drugih etničkih manjina koje su bile u tranziciji iz starog svijeta u novi. Park je opisao pritiske koje su imigranti iskusili životom u različitim kulturama, a zbog lošije integracije u odnosu na dominantne kulture i status autsajdera, Park je imigrantski status nazvao marginaliziranim. Marginalni čovjek za

1 Ovaj je rad financiralo/sufinanciralo Sveučilište u Rijeci projektom (uniri-drustv-18-184 / 5906) i projektom (uniridrustv-18-124 / 1263). 
Parka je zbunjen stranac koji se na putu uspješne asimilacije pridružio dominantnoj kulturi i žrtvovao svoje etničke osobitosti u loncu za topljenje. Na fenomenu marginalizacije rad je nastavio Edwin Stonequist (1937) koji je proučavao hibridne identitete osoba uhvaćenih između dvije vatre (Stonequist, 1937). Od tada je upotreba marginaliziranosti procvjetala, a koncept je kontinuirano proširivan (Billson, 2005). Koncept marginalizacije moguće je analizirati kroz diskurs neoklasične ekonomije, marksizma, teorija socijalne isključenosti i druge diskurse. Neoklasični ekonomisti analiziraju marginalizaciju kroz kulturu siromaštva, a marksisti je shvaćaju kao strukturni fenomen endemski vezan uz kapitalizam (Jahan, 2016). Danas su u upotrebi termini marginaliziranost, marginalne skupine, socijalna isključenost te ranjive skupine pod kojim se često misli na iste skupine i/ili pojedince.

lako rasprave o marginalizaciji imaju dugu povijest, znanstvenicima u recentnim vremenima još uvijek predstavlja izazov kreiranje definicije marginalizacije koja je sposobna tu pojavu pokriti u različitim socio-prostornim uvjetima i različitim pokazateljima marginalizacije. Nepostojanje obuhvatne definicije ukazuje na složenost tog fenomena pa je marginalizacija ostala često raspravljana tema u različitim diskursima koje obuhvaćaju širok spektar njezinih pojavnosti od udaljenih ruralnih regija do urbane populacije ili/i pojedinca u nepovoljnom položaju (Pelc, 2017).

Priroda marginalizacije varira u različitim okruženjima i analitički alati koji se mogu koristiti u većini slučajeva uključuju određenu grupu i/ili pojedince u odnosu prema specifičnim društvenim, kulturnim, ekonomskim, političkim uvjetima u određenoj zemlji. Drugačije rečeno, vjerski, ideološki sustav (patrijarhata), politička ekonomija zemlje i ukupni društveni sustav imaju svoj utjecaj na marginalizaciju. Marginalizacija je proces u kojem grupi ili/i pojedincu nije dopušten pristup važnim pozicijama i simbolima ekonomske, vjerske ili političke moć u društvu (Wacquant,1999). Važnim se naglašava da pri određivanju marginalizacije numerički kriterij nije primaran jer marginalizirana grupa može biti numerička većina, ali ne participira u političkoj ili ekonomskoj moći (Murshed Marlsoob, 2002). Pored numeričkog kriterija, marginalizacija stanovništva može se mjeriti na temelju kombinacije relevantnih pokazatelja kao što je visoka stopa dugotrajne nezaposlenosti, niska razina obrazovanja, diskriminacija, velika izloženost zdravstvenim rizicima ili nedostatak pristupa zdravstvenoj zaštiti (Economic Commission, 2011). Billson (2005) sugerira da u znanstvenim diskursima marginalnost je moguće analizirati na trima razinama: 1. kulturna marginalnost koja se odnosi na dvojbe kultura i asimilacija; 2 . marginalnost društvene uloge koja opisuje napetosti koje se javljaju kada je pojedinac ograničen pripadnosti pozitivnoj referentnoj skupini; 3. strukturna marginalnost koja se odnosi na nemanje utjecaja na političku, društvenu i ekonomsku sferu.

Zbog različitih pokazatelja koji mogu ukazivati na marginaliziranost, marginalizirane skupine nisu homogene. U marginalizirane skupine ubrajaju se osobe bez obrazovanja, žene, osobe bez zaposlenja, osobe drugačije seksualne, političke i vjerske orijentacije, siromašni, starije osobe, invalidi i ostali koji su povremeno ili trajno marginalizirani. Unatoč priznanju da je marginalizacija proces koji rezultira trajnim društvenim nejednakostima, mnoge međunarodne organizacije koriste postignuti stupanj obrazovanja kao kriterij za marginalizaciju (Dejaeghere i Lee, 2011). Koristeći stupanj obrazovanja, Global Monitoring Report (GMR) određuje marginalizirane osobe kao one koje su školovane manje od četiri godine, a UNESCO (2010) navodi da su obrazovno marginalizirane osobe koje imaju četiri godine obrazovanja odnosno da su ekstremno marginalizirane osobe koje imaju dvije godine školovanja. Definiranje marginalizacije prema obrazovanju pretpostavlja da je određena razina obrazovanja inherentni kapacitet za dobrobit i za smanjivanje društvene nejednakosti. Međutim, obrazovna marginaliziranost teško je odvojiva od identiteta grupe (i pojedinca) poput etničke pripadnosti, rase, jezika ili kulture koji su izražena prepreka u obrazovanju te se odražava na siromaštvo. Osobe koje žive u sirotinjskim četvrtima, udaljenim seoskim područjima ili područjima pogođenim sukobima tipično su među najsiromašnijima i najranjivijima skupinama u svakom društvu. Učinci siromaštva snažno uvjetuju društvene stavove koji veliki dio populacije na globalnoj razini pozicionira na rub, a osim 
Sofija Vrcelj, Siniša Kušić, Anita Zovko NEODRŽIVOST TRADICIONALNOG OBRAZOVANJA U..

toga, najsiromašnija kućanstva često ne mogu osigurati da njihova djeca pohađaju školu ili odustaju kada se obitelji suočavaju s vanjskim nedaćama poput suša ili poplava.

Suvremena ekonomska i društvenih dinamika proizvela je masovnu nezaposlenost i nesigurnost na radnom mjestu. U suvremenim neoliberalnim društvima državne i javne institucije postupno osiromašuju odgovornost i brigu o potrebama svojih stanovnika kako bi potaknuli mehanizam kapitalizma koji se temelji na stvaranju nejednakosti i oskudica. Vladajuće klase i vlada elite bogatih nacija pokazale su se, u različitoj mjeri, nesposobnima ili nespremnima zaustaviti porast nejednakosti i marginalnosti (Wacquant, 2006, prema Cummins, 2016).

Bolest, koja je snažan generator marginalizacije, dokaz je da pokazatelji marginalizacije ne moraju uvijek biti opipljivi. Procjenjuje se da je 150 milijuna djece širom svijeta suočeno $s$ poteškoćama u vezi s nekom kroničnom bolešću, a na globalnoj razini procjenjuje se da je u 2007. godini živjelo 33 milijuna ljudi koji su se nosili s poteškoćama izazvane HIV-om i AIDS-om (https://www.who.int/chp/chronic_disease_report/full_report.pdf). Osobe koje imaju navedene bolesti suočavaju se s različitim izazovima, dijele iskustva diskriminacije i stigmatizacije koje ograničavaju njihove mogućnosti obrazovanja, zapošljavanja i drugih aktivnosti pa su stavljene u marginalizirani položaj. Nadalje, osobe s mentalnim poteškoćama, osobe sa specifičnim bolestima ovisnosti, osobe koje su klasificirane kao kriminalci stigmatizirane su i ostaju stigmatizirane čak i nakon djelotvornog liječenja ili dovršavanja kazne i rehabilitacije što ih čini gotovo trajno marginaliziranima (Kreek, 2011).

Nakon uvoda u marginalizaciju, u nastavku rada se analiziraju postojeći koncepti i modeli obrazovanja koji marginaliziraju određene skupine i pojedince. Cilj je rada ukazati na potrebu redizajniranja tradicionalnih oblika poučavanja radi stvaranja obrazovnih okruženja koja su poticajna za sve sudionike obrazovnog procesa. Pod tradicionalnim modelima poučavanja podrazumijevamo obrazovna okruženja u kojima se nude gotove norme kojih se praktičari trebaju pridržavati bez mogućnosti kritičkog propitivanja.

\section{Obrazovna marginalizacija}

Marginalizacija u obrazovanju proizvod je toksičnog koktela naslijeđenih nedostataka, duboko ukorijenjenih društvenih procesa, nepravednog ekonomskog aranžmana i loše politike (Watkins, 2010). Da obrazovni sustavi nisu kreirani po mjeri svih, vidljivo je gotovo permanentno interveniranje u policydokumente i obrazovne sustave na globalnoj i nacionalnoj razini radi razvoja obrazovanja. Na globalnoj razini poznat je svjetski forum obrazovanja u Dakaru 2000 (Obrazovanje za sve, Dakar, 2000), koji je postao mjerilo za procjenu napretka prema obrazovanju za sve. Osim njega i ostali, poput primjerice Education for All Global Monitoring Report 2010; Learning for All: Investing in People's Knowledge and Skills to Promote Development; Making Education a Priority in the Post-2015 Development Agenda,dokumentSvjetske banke Learning for All: Investing in People's Knowledge and Skills to Promote DevelopmentWorld Bank Group education strategy 2020 (World Bank, 2011), iznimno su utjecajni jer nastoje dosegnuti globalnu razinu donositelja odluka i politika, obrazovnih praktičara i međunarodnih institucija za financiranje. Dokument Learning for All: Investing in People's Knowledge and Skills to Promote DevelopmentWorld Bank Group education strategy 2020 predstavlja 10-godišnju strategiju Svjetske banke za postizanje cilja obrazovanja za sve reformom obrazovnog sustava usmjerenog na poboljšanje ishoda učenja te procjenu znanja i postignuća učenika koji pokrivaju temeljne kompetencije čitanja i računanja i vještine kritičkog razmišljanja. lako se mijenja stanje u obrazovanju, još uvijek postoje skupine koje su u obrazovanju marginalizirane pa se može reći da nastojanja obrazovnih političara imaju status dobre retorike. Dok mnoge zemlje podržavaju načela jednakosti i univerzalnih prava, praksa pokazuje da, kada je riječ o mogućnostima za obrazovanje, neki su više jednaki a drugi - marginalizirani - najmanje su jednaki. Nejednakosti povezane s roditeljskim prihodom, rodom, etničnosti, rasom i drugim čimbenicima ograničavaju životne mogućnosti. Osobe koje nemaju (osnovno) obrazovanje susreću se s različitim 
preprekama (Flynn, Brown, Johnson i Rodger, 2011) koje ih još više marginaliziraju jer nemaju kontrole ni pristupa raspoloživim resursima, a to rezultira nemogućnošću uključivanja u svijet rada, sudjelovanjem u lokalnoj i široj zajednici što vodi do daljnje marginalizacije.

Obrazovni sustav neodvojivi je dio društva (države) u kojem se odvija svrhovit proces prenošenja od društva odabranih relevantnih kulturnih i drugih normi što znači da je marginalizacija prisutna u tom dijelu društvene djelatnosti. Obrazovni sustav jedna je takva sfera u kojoj se odvija marginalizacija. Teorija društvene reprodukcije pokazuje kako obrazovanje legitimizira i reproducira društvene, kulturne i gospodarske podjele i klase (Bowles i Gintis, 2002; McLaren i Rikowski,1999).

lako je marginalizacija prisutna, marginalizacija u obrazovanju ostaje relativno neistražen koncept i malo je praktične usmjrenosti na njezino definiranje ili na konceptualizaciju. Recentna literatura orijentirana je na nekoliko tema uključujući spol, nejednakost, inkluzivno obrazovanje i pojedinačne marginalizirane skupine u nastojanju da dadu široku sliku gdje i kada obrazovanje generira marginalizaciju usredotočujući se na globalnu izvanškolsku populaciju ili na nejednakosti između različitih skupina prema kriteriju dobi i spola. Međutim, nedostaci u dijagnozi obrazovne marginalizacije i dalje su očiti i prelaze kriterije dobi, spola ili procesa isključivanja (Watkins, 2010).

Nepostojanje općeprihvaćene definicije marginalizacije otežava određivanje marginaliziranih u obrazovanju. Problematično je definirati tko je marginaliziran jer rijetko postoji dogovorena definicija u bilo kojoj zemlji, a kamoli u krosnacionalnoj analizi. Marginalizacija u obrazovanju nije jednostavna jer na nju djeluje mnoštvo čimbenika, a nedostatak u obrazovanju uzrok je i posljedica marginalizacije u drugim područjima i moćni odašiljač uskraćivanja tijekom više generacija (Klasen, 2001). Često se u analizama prihvaća kvantitativna deprivacija mjerena godinama školovanja ili razinom obrazovanja (Watkins, 2010). Međutim, marginalizacija uključuje i kvalitativnu dimenziju obrazovanja koja se ogleda u nižim razinama postignuća. lako Konvencija o pravima djeteta nameće obvezu vladama da pruže obrazovanje koje vodi razvoju osobnosti, talenta te razvoju kognitivne i fizičke sposobnosti do punog potencijala, iskustva u školama govore o potkopavanju potencijala za učenje jer škole djecu osiromašuju i stigmatiziraju. Kurikulumi su usklađeni s ciljevima i standardima koje je nametnula vlada, a posebne potrebe i stilovi poučavanja kreirani su prema djeci iz urbanih sredina odnosno iz bogati(jih) obitelji (Aliakbari i Faraji, 2011).

Unutar učeničke/studentske populacije postoji subpopulacija učenika/studenata koji su potisnuti na margine svojih zajednica, obitelji, škola i društva. Ti su učenici postali žrtve trenutnih životnih situacija koje utječu na njihov školski angažman i njihove identitete kao učenika (Reyes, 2007). Škole su orijentirane prema visokim rezultatima na standardiziranim testovima, a rezultati su postali način da se učenici sustavno reduciraju na brojčanu vrijednost koja odbacuje sve ono što ih čini ljudskim bićima, jedinstvenim i ranjivim i učenika se pretvara u egzaktnu mjeru - u rezultat na testu. U kulturi školske reforme koja se usredotočuje na postignuća učenika, mjerenih standardiziranim kurikulumom i testiranjem, marginalizirane skupine tradicionalno su manje uspješne. Zagovornici testiranja sugeriraju da kontinuirana procjena napretka i znanja omogućuje nastavnicima i društvu da se čuvaju od mediokriteta koji potkopava konkurentsku prednost zemalja i negativno utječe na svjetsko i nacionalno gospodarstvo (White, 2014). Međutim, postoji zabrinutost zbog neartikulirane svrhe testiranja kao najsnažnijeg sredstva za razvrstavanje prema socioekonomskim i jezičnim razlikama kao i stvaranje kategorije marginaliziranih učenika koji su ispod standarda. Time se testiranje pretvara u primarno sredstvo za klasificiranje i razvrstavanje učenika u obrazovnom sustavu čime obrazovanje gubi funkciju promicanja demokracije, poštovanja i tolerancije.

Za učenike koji dolaze iz visokorizičnih skupina, obojeni, siromašni, migranti, djeca koja imaju ograničeno znanje engleskog jezika i drugi, uspjeh u današnjim školama je ograničen, a nisko samopouzdanje i samopoštovanje djece može ih nepovratno oštetiti (Larson, 2010). 
Obrazovni sustav podržava standardnu jezičnu ideologiju i djecu koja su iz marginaliziranih skupina u školama uče da je standard superiorniji i po strukturi i po važnosti dok su jezične i govorne strukture marginaliziranih inferiornije što može dovesti do isključivanja iz obrazovnog procesa i u kasnijem životu od institucija moći. Naviknuti da svako odstupanje od standarda nije dobro, veliki broj ljudi u marginaliziranim društvenim skupinama prihvaća tu ideologiju (Siegel, 2006). Vjera u inferiornost marginalizirane grupe glavni su razlog za trenutnu obrazovnu praksu da ih se drži izvan kurikuluma, a ta praksa pomaže u održavanju uvjerenja da su te grupe inferiorne. To je hegemonija standarda (Siegel, 2006), a prema Gramsciju hegemoniju su organizirali intelektualci, a zadatak im je oblikovati moralni i intelektualni život te provoditi kontrolu. Kreatori (nacionalnih) kurikuluma stvaraju od učitelja obrazovne tehnokrate obvezujući ih da budu odašiljači službeno priznatih znanja bez orijentacije na razvoj učenikovih potencijala te kurikulumi služe kao alat za legitimaciju i kontinuiranu kontrolu znanja. U današnje vrijeme znatna većina prakse obrazovanja vođena je instrumentalnim pristupom, a podrazumijeva da je učenik menadžer svojih kompetencija i da njegov razvoj ovisi o sposobnosti da svoje kompetencije prilagodi tržištu rada što se može shvatiti kao „instrument prilagodbe, a ne emancipacije" (Biesta, 2012: 8). Takav pristup obrazovanje uglavnom shvaća kao sredstvo prilagodbe potrebama i zahtjevima političkog i ekonomskog konteksta pri čemu se znanje promatra kao nešto što je izvan učenika, a koje će se steći u procesu učenja.

U obrazovanju je snažno izražen politički pritisak i nadzor od strane države s ciljem da se formira idealan pojedinac prema shvaćanju političkih, ali i korporativnih elita (Kušić, Vrcelj i Klapan, 2014). Upravo iz tog razloga u obrazovnim politikama, kako ističu Clabaugh i Rozycki (1990), prevladava disciplina forme (Učini to na ovaj način! Zašto? Zato jer je tako ispravno.), a ne disciplina uzroka (Učini to na ovaj način! Zašto? Zato što djeluje.).

Nastavljajući se na Gramscijeva promišljanja kako je je u zapadnom društvu država okružena i poduprta mrežom ideoloških društvenih institucija koje se shvaćaju kao „snažan sustav utvrda“, odgojno-obrazovne ustanove nisu „neutralne“ i služe da se učvrsti postojeća hegemonija. Ono što često ostaje skriveno, jer je postalo „zdrav razum“, odnosno zauzima autoritativnu poziciju istine i stoga se teško prepoznaje, pretpostavke su koje leže u osnovi koncipiranih teorija, a proistekle su iz zapadnoevropskog diskursa u kome je sadržan odgovor na pitanja: što je istina, tko je proizvodi, što je znanje, tko ga posjeduje, kako se do njega dolazi i kakvi su odnosi moći u obrazovanju? Sukladno tim pitanjima Maksimović (2012) ističe kako je praksa u velikoj mjeri oblikovana i postojećim teorijama učenja koje imaju posredan utjecaj na kreiranje institucionalnih okvira, oblika obrazovanja, kurikuluma, ishoda učenja, metoda rada i na rad onih koji poučavaju. Teorije učenja nisu neutralne, već inkorporiraju određenu ideologiju i sustav vrijednosti o poimanju znanja, a pitanje je i koliko određene teorije učenja potencijalno reproduciraju odnose moći u obrazovanju.

Kreiranje kurikuluma treba u sebi sadržavati futurističku dimenziju pa je važno da sadrži prijedloge za djelovanje učitelja. Učitelji trebaju imati prostora za djelovanje radi davanja doprinosa zajednici, radi kreiranja nacionalnih i svjetskih vrijednosti koje pravedno i tolerantno postupaju prema drugačijim. Kurikulumi orijentirani na promjene neće učitelje ostaviti nemoćnim u ostvarivanju stvarnog rasta i emancipacije pojedinca (Watkins, 2010). Isto tako, u realizaciji kurikuluma učitelji bi trebali u evaluaciji uključiti svoja uvjerenja o tome što bi zajednica trebala biti i kako bi se osigurali da ulaganja u obrazovanje donose dugoročne dobre rezultate za sve, a ne samo onima koji pripadaju ili teže članstvu u obrazovnoj hegemoniji (Siegel, 2006; White, 2014). Kako ističe J. Dewey (1966), obrazovanje treba pridonositi društvenoj integraciji, općem poboljšanju društva i biti poticaj pojedincima da razviju svoj puni potencijal.

Intelektualna funkcija unutar određenog društva uvijek je obrazovna i politička, a intelektualci su određeni funkcijom političkog i tehničkog vodstva (Monasta, 1993, prema Vrcelj, 2018). Obrazovanje je područje na kojem se teorija i praksa, kultura i politika neizbježno stapaju. Čelnici trebaju priznati da dijete i njegovo postignuće nije lako odvojiti od socijalnih, emocionalnih i gospodarskih previranja koja često potkopavaju njegove stvarne prilike za učenje 
(Warikoo i Carter, 2009). Aktivnosti radi socijalne pravde ne bi trebale biti odvojene od (cilja) postignuća učenika, a podučavanje za socijalnu pravdu djelotvorno smanjuje nedostatke postignuća zbog rase, klase, spola i drugih okolnosti koje utječu na marginaliziranost. Zbog heterogenosti obrazovnog materijala nameće se potreba uvažavanja i življenja multikulturalnosti. Kritički diskurs koncepata multikulturalnog kurikuluma i obrazovne prakse tvrdi da nisu donijeli značajne promjene koje su imale blagotvoran utjecaj na marginalizirane pojedince i/ili grupe. Te se kritike odnose na redukcionističko stajalište inherentno kurikularnim prikazima različitosti u kojima se kultura shvaća kao skup praksi i artefakata dominantne grupe koja se nameće prihvatljivom za društvo u cjelini. Obrazovanje daje svjetonazore koji pojedince marginaliziraju, a takvo stanje moguće je mijenjati promicanjem interesa marginaliziranih, praksom socijalne jednakosti i uspostavljanjem epistemološkog prostora za pitanja različitih iskustva, kulture, identiteta, snage, jednakosti i diskriminacije (Banks i Banks, 1995). Nadalje, multikulturalno obrazovanje nije dalo značajne pomake u akademskim postignućima marginaliziranih i nije uspjelo ublažiti djelovanje prisilnih odnosa moći (Carl E. i Schecter, 2000). Štoviše, obrazovni političari gledaju na kulturnu raznolikost kao zapreku nacionalnom jedinstvu i konkurentnosti u globalnom kontekstu čime je multikulturalno obrazovanje daleko od toga da bude koncept, smjer reforme obrazovanja, proces i praksa koji nastoje održati dijalog između članova različitih kulturnih skupina koje čuvaju svoje posebne kulture. (Multikulturalno) obrazovanje treba biti emancipatorno, kako ističe Freire (2002), koje će transformirati nepravičan sustav odnosno multikulturalno obrazovanje treba obuhvaćati kurikulum, pedagoški pristup, smanjenja predrasuda, razumijevanje politike o tome kako je znanje konstruirano i čije je znanje povlašteno. Multikulturalno obrazovanje podrazumijeva više od jednog sata, jedinice, mjeseca, razreda, učitelja ili ciljne skupine, već mora biti središnja jezgra filozofija obrazovne politike i prakse unutar određenog sustava (Banks, 2001).

Mladi koji su obrazovno marginalizirani često bivaju marginalizirani i u odrasloj dobi. Kategorija mladih i odraslih društveno su konstruirane i ovise o nizu društvenih, kulturnih i političkih čimbenika koji zajedno određuju kada društvo smatra da netko ima status mlade odnosno odrasle osobe (Kušić, Vrcelj i Zovko, 2016). Definiranje mladosti i odraslih važno je za kreatore obrazovne politike koji trebaju biti u stanju identificirati jasno razgraničenu ciljnu skupinu. Najčešće su odrasli kategorija starosne dobi čije gornje i donje granice ovise o narativima koje formuliraju sami donositelji politika (Ranzijn, 2010), a koje mogu pridonijeti repozicioniranju te često marginalizirane skupine.U Europi se odrasli često određuju osobama iznad 30 godina što otežava konceptualizaciju obrazovanja i zapošljavanja. S obzirom na znatne ekonomske razlike unutar europskog prostora, biološka je dob problematičan kriterij budući da je, primjerice, materijalna neovisnost i osobna autonomija važniji kriterij koji dijeli mlade od odraslih (Shanahan, 2000). Kriterij svrstavanja i ostalih marginaliziranih skupina i pojedinaca problematičan je jer je važno razmišljati o fluidnoj i složenoj prirodi marginalizacije kako bi se istražili mogući načini njihovog repozicioniranja. U europskom prostoru postoje stare i nove društvene skupine koje trpe isključenost poput Roma, imigranata i izbjeglica ili osoba niskog stupnja školovanja i za koje je veća vjerojatnost da će biti nezaposlene, siromašne i/ili diskriminirane. Osim toga, postoji značajan broj učenika koji se svrstavaju u kategoriju marginaliziranih, a čija iskustva ne moraju biti tipično marginalizacijska kao što, na drugoj strani, postoje učenici koji ne pripadaju marginaliziranim, ali čija iskustva idu u prilog njihovoj marginalizaciji (Kyriaki, 2017). Te poteškoće kategorijalne naravi aktualiziraju drugačije koncepcije obrazovanja radi pronalaženja puteva za prevladavanje marginalizacije jer je potrebno razumjeti promjene u društvu i mehanizme inkluzije u obrazovanju.

\section{Osnaživanje marginaliziranih obrazovanjem}

Pojam osnaživanje proizišao je iz socijalne i obrazovne psihologije, a označava strategiju za pojedinca kojom će zadržati kontrolu nad ključnim aspektima svog života (Cunningham et al, 
1996, str. 144). Taj se konstrukt može koristiti u različitim kontekstima pa tako i u kontekstu poboljšanja položaja marginaliziranih, neorganiziranih i drugih socijalno ugroženih dijelova društva. Isto tako, osnaživanje predstavlja nade i snove marginaliziranih skupina za društveno okruženje oslobođeno nejednakostima u različitim područjima života. Osnaživanje obrazovanjem konstrukt je koji je kreirao Freire, a koji se često koristi u recentnim diskursima o razvoju iako nema jasnu definiciju. Osnaživanje treba uključivati kognitivnu, psihološku, političku i ekonomsku komponentu. Kognitivna komponenta može se osnažiti obrazovanjem koje daje relevantna znanja da bi se razumjeli uvjeti podređenosti i marginalizacije na mikro i makro razini.

U obrazovanju osnaživanje je na neki način pomicanje moći od vlade do učitelja i od učitelja do učenika i predstavlja potencijal za brisanje razlika u moći između njih (Deacon i Parker, 1995, prema Lawson, 2011). Na razini škola osnaživanje je proces u kojem sudionici razvijaju kompetencije potrebne za preuzimanje odgovornosti za vlastiti rast i rješavanje vlastitih problema. Osim razine škole osnaživanje se iskazuje i na međunarodnoj i nacionalnoj razini tako što se daje dopuštenje nastavnicima da prilagode kurikulume i pedagogiju kako bi se zadovoljile potrebe učenika. Prihvaćajući Freirove postavke obrazovanja odnosno osnaživanja, Giroux (1997) osnaživanje stavlja u kontekst kolektivne borbe za život bez ugnjetavanja i eksploatacije i izražavanje „glasova“ učenika i učitelja koji mogu biti emancipatorski u različitom stupnju. Emancipatorska snaga obilježena je političkim kontekstom koji na jednoj strani proizvodi marginalizirane i na drugoj strani daje im ili oduzima moć i mogućnosti za promjene.

Kako masovno obrazovanje nikada nije bilo ravnopravno, demokratsko, kritično ili uključivo, usprkos velikoj legendi o školi koja ih mistificira kao velike ekvalizatore (Matusov, 2017), snaga obrazovanja u eliminiranju marginalizacije ogleda se u osposobljavanju sudionika da tijekom obrazovnog procesa razvijaju kompetencije radi preuzimanja odgovornosti za vlastiti rast. Dijeljenje moći među onima koje je imaju i onih koji je nemaju jedna je od pretpostavki osnaživanja (Foucault, 1980, prema Cummins, 2016). Za Foucaulta moć nije konačni entitet koji se može locirati; moć je relacija, a ne supstanca i nešto je što postoji samo u društvenim akcijama. Drugačije rečeno, moć je pristup mogućnostima i stoga je povezana s mogućnošću da se pokrene nešto novo, a ako nema moći odnosno mogućnosti, vjerojatno će osoba trajno ostati marginalizirana. Osnažena osoba ima vještine i znanje kojima može djelovati na situaciju te ju poboljšati. Međutim, da bi se to ostvarilo, odgojno-obrazovno okruženje trebalo bi pružiti mogućnosti za razvoj i pokazati kompetentnost u rukovanju različitim situacijama, što učitelje čini središnjim u tom procesu. Tradicionalno obrazovanje često odbacuje dijalog kao alat za premošćivanje jaza u društvenoj, kulturnoj i ekonomskoj nejednakosti. Dijalog koji je zapravo sve prisutniji u našim društvenim odnosima, od intimnosti naših domova do visokih političkih sfera, treba biti podloga učenju i obrazovanju. U tom smjeru, dijalog je više od razgovora, on je izgradnja zajedničkog narativa (Flecha, 2011) i komunikacijska interakcija koju karakterizira poštovanje, briga i uzajamnost među sudionicima (Freire, 2002). Kritički dijalog operacionalizira transformativno, osnažujuće obrazovanje praksom kritičkog razmišljanja potaknutog od strane učitelja u sigurnom, komunikativnom obrazovnom okruženju. Okvirom utemeljenim na ljudskim pravima učenici imaju alate potrebne da svoju društvenu svijest pretvore u društvenu promjenu i mogućnost autonomnog samoodređenja. Ono što je najvažnije, cilj je kritičkog dijaloga dati glas učeničkim mislima, izraziti njihove brige i osjećaje te koristiti vlastita iskustva i osjećaje kao valjani izvor znanja. Sudjelujući u međusobnom autentičnom kritičkom dijalogu, učenici kolektivno pronalaze načine jačanja, odupiranja silama dominacije i transformiranju svojih života (Padrós i Flecha, 2014; Hayes, Steinberg i Tobin, 2011).

Obrazovanje treba koristiti mogućnosti povećanog dijaloga kako bi socijalni modeli obrazovanja, proizišli iz najšireg okruženja, uvažavali zahtjeve ljudi te potaknuli participativnu demokraciju u odgojno-obrazovnim institucijama. Tako koncipirane, institucije s dijaloškom orijentacijom postižu veći uspjeh i povećavaju sudjelovanje učenika ne samo u odgojno-obrazovnim institucijama nego i u lokalnim zajednicama (Padrós i Flecha, 2014). U tradicionalnim pristupima obrazovanju zanemareno je dijaloško učenje (Flecha, 2011) utemeljeno na načelima 
ravnopravnog dijaloga, transformacije, solidarnosti, a odgovara interesima, potrebama i kompetencijama sudionika uključenih u proces učenja. Na taj se način obrazovanje debirokratizira jer svi sudjeluju u stvaranju znanja koje je izgrađeno zajednički na temelju egalitarnog dijaloga i zajedničkog iskustva (Flecha, 2011). Prostor za dijalošku interakciju stvara mogućnosti marginaliziranima da prevladaju društvene, kulturne i obrazovne barijere koje ih isključuju iz punog sudjelovanja na tržištu rada, daljnjem obrazovanju i drugim društvenim sferama (Fecha, 2011; Padrós i Flecha, 2014; Freire, 2002). Sudjelovanje u obrazovanju znači angažiranje sudionika procesa u procesu donošenja odluka, procjenjivanja i definiranja ciljeva u organizaciji u kojoj se realizira demokratsko obrazovanje.

Moć shvaćena kao niz mogućnosti generira se razmišljanjem i dijeljenjem $\mathrm{s}$ drugima $\mathrm{i}$ ovisi o osnaživanju sudionika dajući im dopuštenje za razmišljanje. U davanju dopuštenja za razmišljanje važna je uloga nastavnika koji trebaju stvarati uzajamne, izjednačavajuće odnose s roditeljima i zajednicama kako bi podržali uspjeh učenika u razredu i minimizirali utjecaj obitelji koja je lošijeg ekonomskog statusa. Nadalje, škole bi trebale tražiti načine radi uključivanja raznolikosti kulturnih i etničkih pozadina u učionice, oslanjajući se na iskustva i znanja učenika. Uvažavajući učenike, nastavnici trebaju koristiti pedagoški i andragoški pristup kurikulumu koji omogućuje različite perspektive, posebice perspektive marginaliziranih, i pristupe učenju te poticati kritičko mišljenje (Adair, 2015). Da bi se sudionici obrazovanja pripremili za kritičko mišljenje, kritička pedagogija treba sići u nastavni proces (učionicu) povezujući društvenu razinu s osobnom razinom. Za repozicioniranje marginaliziranih skupina i/ili pojedinaca nije dovoljno priznati postojanje represivnih struktura moći, već treba kritički ispitati te društvene i političke uvjete kako se odražavaju u vlastitom živom iskustvu. Učenici trebaju učiti kako se kritički odnositi prema svijetu koji ih okružuje povezujući impersonalne intelektualne koncepte i teorije sa stvarnošću svojih života i pitajući se zašto je to prisutno (Hayes, Steinberg i Tobin, 2011).

\section{ZAKLUČAK}

U radu smo nastojali istaknuti glavne uzroke i posljedice marginalizacije u obrazovanju. Analiza je pokazala da obrazovna marginalizacija najčešće generira i ostale oblike marginalizacije. Durkheimova teorija o društvenim promjenama tvrdi da je promjena u obrazovanju moguća samo ako je društvena struktura u kojoj se nalaze društvene institucije obrazovanja promijenjena (Cvjetićanin i Supek, 2003, prema Vrcelj, 2018) pa je realna pretpostavka smanjenja marginalizacije u obrazovanju i mijenjanje društvenog konteksta koji je generira. Škole postoje u složenom društvenom kontekstu koji se sastoji od vanjske politike, vlade i utjecaja zajednice. Da bi se implementirala održiva promjena, obrazovni političari trebaju gledati na cijeli sustav u kojem se škole nalaze (Banks i Banks, 1995). To znači da isti društveni, ekonomski i politički procesi koji stvaraju marginalizaciju i nepravdu također imaju moć da je smanje ili eliminiraju. Škole su moćna mjesta za promjene i društvenu transformaciju i sposobne su organizirati školske strukture, razvijati pedagogiju i kurikulume na načine koji će osnažiti učenike da ostvare svoj puni potencijal. Kako je marginalizacija u obrazovanju još uvijek nepopravljena nepravda, od vitalne je važnosti prevesti politiku u djelotvorne nastavne planove i programe, programe obuke nastavnika i praksu u učionici. Marginalizacija nameće važnim pažljivo razmatranje što i kako podučavamo u školi uz proširivanje znanja koja izlaze iz uskog fokusa ishoda učenja na cjelovitiji životni ishod koji pojedinca neće marginalizirati. Da se ne bi ostalo na razini dobre retorike, treba uspostaviti mehanizme koji će omogućiti reforme i inovacije obrazovanja na svim razinama te na razini prakse. Kako se još uvijek rukovodi numeričkim kriterijima u okviru tradicionalnog obrazovanja, značajan doprinos dala bi analiza marginalizacije izvan formalnih oblika obrazovanja. Dosadašnje su akcije pokazale nemoć tradicionalno koncipiranog obrazovanja u suzbijanju marginalizacije te je stoga krucijalno redizajniranje kurikuluma, uvažavanja osobnih veoma heterogenih iskustava i strategija poučavanja radi osnaživanja sudio- 
Sofija Vrcelj, Siniša Kušić, Anita Zovko NEODRŽIVOST TRADICIONALNOG OBRAZOVANJA U...

nika obrazovnog procesa. Ostvarivanje promjena u obrazovanju svakako će smanjivati i/ili eliminirati marginalizaciju. Pri tome je neophodno potrebno nastavnike shvaćati kao agente promjena koji će preoblikovati postojeće prakse, a koji se u reformama obrazovanja u mnogim zemljama eksplicitno tako i određuju. lako je dominirajuća politika usmjerena prema deprofesionalizaciji jer su nastavnici bili shvaćeni kao izvršitelji određenih kurikuluma radi ostvarivanja represivnog režima testiranja i zadovoljavanja kriterija vanjskog vrednovanja ( Priestley, Biesta i Robinson, 2012), pomaci u shvaćanju uloge nastavnika daju nadu u promjene. Kako kurikulum najčešće odražava dominantnu kulturu, nastavnici u radu s učenicima mogu ukazati na faktore, iskustva i probleme s kojima žive marginalizirani odnosno na njihov socio-kulturalni život. Na taj način stvaraju se stvarne osnove da formalno obrazovanje postane platforma za širenje demokratskih ideja koje su čiste od marginalizacije.

\section{LITERATURA}

Aliakbari, M. i Faraji, E. (2011). Basic Principles of Critical Pedagogy. 2nd International Conference on Humanities, Historical and Social Sciences IPEDR, 17 (2011).

Adair, J. (2015). The impact of discrimination on the Early Schooling Experiences of Children from Immigrant Families. Washington: Migration Policy Institute.

Banks, C. A. M. i Banks, J. A. (1995). Equity pedagogy: An essential component of multicultural education. Theory Into Practice, 34(3), 152-158.

Banks, J. A. (2001). Approaches to multicultural curriculum reform. U: J. A. Banks \& C.M. Banks (ur.), Multicultural Education: Issues and Perspectives (4. izd., str. 225-246). New York: Wiley.

Bankovskaya, S. (2014). Living in-between: The Uses of Marginality in Sociological Theory. Russian sociological review, 13(4), 94-104.

Bowles, S. i Gintis, H. (2002). Schooling in Capitalist America Revisited. Sociologyof Education, 75(1), 1-18.

Biesta, G. (2012). Have lifelong learning and emancipation still something to say to each other? Studies In The Education Of Adults, 44(1), 5-20.

Billson, J. M. (2005). No Owners of Soil. Redefining the Concept of Marginality, U: Dennis, Rutledge M. (ur.), Marginality, Power and Social Structure: Issues in Race, Class and Gender Analysis (str. 29-47). Oxford: Routledge.

Carl, E. J. i Schecter R. S. (2000). Mainstreaming and marginalization: two national strategies in the circumscription of difference, Pedagogy, Culture \& Society, 8(1),23-41, doi:10.1080/ 14681360000200078

Clabaugh, G. K. i Rozycki, E. G. (1990). Understanding Schools: the Foundations of Education. Chapter 9 - Controlling the School: Institutionalization. NewYork: Harper \& Rowe. Preuzeto s http:// www.newfoundations.com/OrgTheory/Institutionalization.html, 2.4.2019.

Cummins, I. (2016). Wacquant, urban marginality, territorial stigmatization and social work, Aotearoa New Zealand Social Work, 28(2), 75-83.

Cunningham, I., Hyman J. i Baldry, C. (1996). Empowerment: the power to do what?. Industrial Relations.Journal, 27(2), 143-154. doi/10.1111/j.1468-2338.1996.tb00764.x

Dejaeghere, J. i Lee, S. K. (2011). What Matters for Marginalized Girls and Boys in Bangladesh: A Capabilities Approach for Understanding Educational Well-Being and Empowerment. Research in Comparative and International Education, 6(1), 27-42. doi/10.2304/rcie.2011.6.1.27

Déry, S., Leimgruber,W. i Zsilincsar, W. (2012). Understanding Marginality: Recent Insights from a Geographical Perspective. Hrvatski geografski glasnik 74(1), 5-18.

Dewey, J., Djui, Dž. (1966). Vaspitanje i demokratija - Uvod u filozofiju vaspitanja. Cetinje: Obod.

Flecha, R. (2011). The dialogic sociology of education. International Studies in Sociology of Education, 21(1), 7-20. 
Flynn, S., Brown, J., Johnson, A. i Rodger, S. (2011). Barriers to Education for the Marginalized Adult Learner.Alberta Journal of Educational Research, 57(1), 43-58.

Freire, P. (2002). Pedagogija obespravljenih. Zagreb: Odraz - Održivi razvoj zajednice.

Hayes, K., Steinberg, S. R. i Tobin, K. (ur.). (2011). Key Works in Critical Pedagogy: Joe L. Kincheloe. Rotterdam/Boston/Taipei: Sense Publishers.

Jahan, Y. (2016). Intersectionality of Marginalization and Inequality: A Case a Study of Muslims in India. Journal of Political Sciences and Public Affairs 4(1), 1-6. doi:10.4172/2332-0761.1000187

Klasen, S. (2001). Social exclusion, children and education. Implications of a rights-based approach. European Societies 3(4), 413-445.

Kreek M. J. (2011). Extreme marginalization: addiction and other mental health disorders, stigma, and imprisonment. Annals of the New York Academy of Sciences, 1231(1), 65-72. doi:10.1111/ j.1749-6632.2011.06152.x

Kušić, S., Vrcelj, S. i Klapan, A. (2014). (Ne)obrazovni i (ne)odgojni ishodi obrazovanja. U: Hrvatić, N., Lukenda, A., Pavlović, S., Spajić-Vrkaš, V. i Vasilj, M. (ur.): Pedagogija, obrazovanje i nastava sv.1. (str. 419-429). Mostar, Fakultet prirodoslovno-matematičkih i odgojnih znanosti Sveučilišta u Mostaru.

Kušić, S., Vrcelj, S. i Zovko, A. (2016). Didaktičke odrednice obrazovanja andragoga - komparativni pristup. Rijeka: Filozofski fakultet u Rijeci.

Kyriaki M. (2019). Understanding marginalisation through dialogue: a strategy for promoting the inclusion of all students in schools. Educational Review, 71(3), 306-317. doi:10.1080/ 00131911.2017 .1410103

Lawson, T. (2011). Empowerment in Education: liberation, governance or a distraction? A review. Power and Education, 3(2), 89-103.

Matusov, E. (2017). Dialogic \& Critical Pedagogies: An Interview with Ira Shor. Dialogic Pedagogy: An International Online Journal, 5(3), 1-21. doi.org/10.5195/dpj.2017.208

Maksimović, M. (2012). Teorije učenja i odnosi moći u obrazovanju odraslih. Andragoške studije, 1, 37-62.

McLaren, P. i Rikowski, G. (1999). Postmodernism in educational theory. U: Hill, D., McLaren, P., Cole, M. i Rikowski, G. (ur.), Postmodernism in educational theory, education and politics of human resistance. London: The Tufnell press.

Murshed. M. (ur.) (2002). Globalization, Marginalization, and Development, London, New York: Routledge.

Padrós, M. i Flecha, R. (2014). Towards a Conceptualization of Dialogic Leadership. International Journal of Educational Leadership and Management, 2(2), 207-226, doi:10.4471/ijelm.2014.17.

Pelc, S. (2017). Marginality and Marginalization. U: Chand, R. Nel, E. Pelc, S. (ur.). Societies, Social Inequalities and Marginalization. Perspectives on Geographical Marginality: Springer International Publishing.

Ranzijn, R. (2010). Active Ageing - Another Way to Oppress Marginalized and Disadvantaged Elders?: Aboriginal Elders as a Case Study. Journal of Health Psychology, 15(5), 716-723. doi: 10.1177/1359105310368181.

Reyes, R. (2007). Marginalized Students in Secondary School Settings: The Pedagogical and Theoretical Implications of Addressing the Needs of Student Sub-Populations. Journal of Border Educational Research, 6(2), 3-6.

Priestley, M., Biesta, G. i Robinson, S. (2012). Teachers as agents of change: An exploration of the concept of teacher agency : Working paper no. 1, Teacher Agency and Curriculum Change (Researchgate).

Siegel, J. (2006). Language ideologies and the education of speakers of marginalized language varieties: Adopting a critical awareness approach. Linguistics and Education 17(2), 157-174.

Shanahan, M. J. (2000). Pathways to Adulthood in Changing Societies: Variability and Mechanisms in Life Course Perspective. Annual Review of Sociology, 26, 667-692 doi:10.1146/annurev.soc. 26.1.667

Stonequist, E. V. (1937). The marginal man: a study in personality and culture conflict. New York, NY, US: Scribner/Simon \& Schuster. 
Sofija Vrcelj, Siniša Kušić, Anita Zovko NEODRŽIVOST TRADICIONALNOG OBRAZOVANJA U...

Wacquant, L. (1999). Urban Marginality in the coming Millennium. Urban Studies, 36(10), 16391647.

Watkins, K. (2010). Reaching the marginalized - the key to Education for All. Zeitschrift für internationale Bildungsforschung und Entwicklungspädagogik 33(3), 8-11.

Warikoo, N. i Carter, P. (2009). Cultural Explanations for Racial and Ethnic Stratification in Academic Achievement: A Call for a New and Improved Theory. Review of Educational Research, 79(1), 366-394. doi:10.3102/0034654308326162

UNESCO (1990). World Declaration on Education for All. Adopted by the Conference on Education for All. Thailand Jomtien., 5-9 March. UNESCO.

UNESCO (2000). The Dakar Framework for Action. Education for All: Meeting our Collective Commitments. Including Six Regional Frameworks for Action. Adopted by the World Education Forum. Dakar, 26-28 April. UNESCO.

UNESCO (2010). Education For All. Reaching the marginalized. EFA Global Monitoring Report 2010. Paris.

Vrcelj, S. (2018). Što školu čini školom - teorijski pristupi, koncepti i trendovi. Rijeka: Filozofski fakultet u Rijeci.

White W. L. (2014). Curriculum, Marginalization, and the Professoriate. Journal of Inquiry \& Action in Education, 5(3), 91-101.

World Bank (2011). Learning for all: investing in people's knowledge and skills to promote development - World Bank Group education strategy 2020 (English). Washington, DC: World Bank.

Preuzeto s http://documents.worldbank.org/curated/en/169531468331015171/Learning-for-allinvesting-in-peoples-knowledge-and-skills-to-promote-development-World-Bank-Groupeducation-strategy-2020.

\section{The Unsustainability of Traditional Education in Combating Marginalization ${ }^{2}$}

Abstract: The paper analyzes marginalization with special reference to marginalization in education. Although (educational) marginalization is a slippery construct, it exists in all societies and affects different groups of people. Traditional approaches to education that generate marginalization have, despite some attempts, shown all their power to suppress education, which imposes the need to create a different education that will empower the marginalized. At the school level, empowerment is a process in which participants develop the competencies needed to take responsibility for their own growth and solve their own problems, while at the international and national levels, it is a process and actions that allow teachers to adapt curricula and pedagogy to meet students' needs.

Keywords: education, marginalization, adults, curriculum

\section{Ohnmacht traditioneller Bolding bei der Bekämpfung von Marginalisierung ${ }^{3}$}

Zusammenfassung: In dieser Arbeit wird die Marginalisierung mit besonderem Nachdruck auf den Bereich Bildung analysiert. Obwohl Marginalisierung (in der Bildung) ein vages Konstrukt ist, existiert sie in allen Gesellschaften und umfasst unterschiedliche Personengruppen. Traditionelle Bildungsansätze, durch die Marginalisierung entsteht, erweisen sich, trotz gewisser Versuche, machtlos gegen ihre Bekämpfung im Bereich Bildung, was den Bedarf aufnötigt, eine andere Bildung zu schaffen, welche eine Stärkung der Marginalisierten ermöglichen würde. Diese Stärkung kann auf Schulebene als ein Prozess beschrieben werden, in dem die Teilnehmenden Kompetenzen entwickeln, die sie benötigen, um Verant-

2 This work was funded / co-funded by the University of Rijeka with the project (uniri-drustv-18-184 / 5906) and the project (uniri-drustv-18-124 / 1263).

3 Dieser Artikel wurde von der Universität in Rijeka durch zwei Projekte finanziert/mitfinanziert (uniri-drustv-18-184 / 5906; uniri-drustv-18-124 / 1263). 
wortung für eigenen Wachstum und die Lösung eigener Probleme zu übernehmen. Auf internationaler und nationaler Ebene bezieht sich die Stärkung auf den Prozess und die Aktionen, die es Lehrern erlauben Lehrpläne und pädagogische Ansätze anzupassen, damit sie den Bedürfnissen der Schüler entsprechen.

Schlüsselwörter: Bildung, Marginalisierung, Erwachsene, Lehrplan 